Article

\title{
Does Working Capital Affect Family Firms' Decision-Making in Laos? Evidence from a Two-Wave Cross-Lagged Approach
}

\author{
Hanvedes Daovisan ${ }^{1, *(D)}$ and H. L. Shen ${ }^{2}$ \\ 1 Center for Research on Plurality in the Mekong Region, Faculty of Humanities and Social Sciences, \\ Khon Kaen University, Khon Kaen 40002, Thailand \\ 2 College of Management, National Taiwan University, Roosevelt Rd., Taipei City 106, Taiwan; \\ D04741004@ntu.edu.tw \\ * Correspondence: vend@kkumail.com; Tel.: +66-933379255
}

Received: 19 February 2020; Accepted: 23 March 2020; Published: 27 March 2020

check for updates

\begin{abstract}
Family firms are the backbone of the socialist transition to a market-oriented economy in Laos. Working capital is an important area of finance that has not been widely studied in relation to family firms' decision-making. We hypothesize that working capital has a positive cross-lagged effect on decision-making. The hypotheses were tested on a sample of 779 Laotian family firms from 2016 to $2017\left(t_{1}\right)$ and from 2018 to $2019\left(t_{2}\right)$. The analysis was performed using a two-wave cross-lagged model under structural equation modelling. Our results confirm that working capital (access to finance, cash, debt financing, inventory, growth, and profitability) has a positive cross-lagged effect on decision-making. In addition, the findings also suggest that family firms' early-debt financing could have a vital influence on decision-making. The practical implications of the results are discussed.
\end{abstract}

Keywords: working capital; decision making; family firms; two-wave cross-lagged model; Laos

\section{Introduction}

Working capital is the key management challenge for all family firms, as it affects their capital budgeting, liquidity, and profitability [1,2]. In the mainstream debate about challenges to firms, it is estimated that for $70-80 \%$ of family firms, working capital is their greatest problem [3]. Many scholars have determined that working capital does not only trickle from the optimal stock of capital and competition, but is also a crucial effect of decision-making [4-6]. Small-scale evidence for family firms is limited [7], given the difficulty of obtaining reliable data on decision-making during times of financial market recession. Operational working capital limitations are not always the most rational option; preferable is the return on assets of family firm performance [8].

As with all growing economies, Laos needs to develop its family firms, which are the key engine for all Association of Southeast Asian Nations (ASEAN) countries as developing world nations. As previous studies have noted, ASEAN countries showed high growth in family firms after Laos, Vietnam, and Cambodia and Myanmar opened their economies in 1986, the early 1990s, and the year 2000, respectively, with the latter decade being of market liberalization globally $[9,10]$. Moreover, in terms of gross domestic product since 2018, family firms in Laos have contributed 38.36\%, in Vietnam $36 \%$, in Cambodia 36.4\%, and in Myanmar 50\%. This region is an economic corridor connection that creates global market liberalization strategies between domestic and foreign trade. Academically, Eddleston et al. [11] have identified that the effect on working capital and decision-making is seen in increased liability, liquidity, and return on assets.

Laos is a relatively small country that has kept up with rapid economic growth, with 125,616 (98.8\%) family firms and only $196(0.2 \%)$ company enterprises. According to Onphanhdala and 
Suruga [12], Sayvaya and Kyophilavong [13], and Daovisan and Chamaratana [14], promoting family start-ups is one of the highest priorities in the national socioeconomic development plan. This involves easing legal aspects, improving access to finance, enhancing competitiveness, and connecting domestic and international markets. The industrial transformation in Laos is affecting working capital, which in turn influences wise decision-making $[15,16]$. However, despite the urgent need to understand more about family firms in Laos, there is very limited research data available, particularly in terms of empirical studies.

It is therefore surprising that relatively few studies have examined how working capital affects decision-making [17,18]; instead, most research has focused on profitability. This finding is consistent with those of Molly et al. [19], and Yazdanfar and Öhman [20], who showed that family firms prefer using external capital sources when making debt decisions. This empirical study, however, fails to account for the importance of access to finance, cash, inventory, growth, and profitability [21-24]. It is therefore desirable to develop studies on this issue. Hence, it is more important to examine not only whether, but also why working capital affects decision-making. We examined a large dataset of Laotian family firms over the 2016-2019 period, analyzed using a cross-lagged model.

The present study adds several contributions to the literature. First, we aim to elicit the importance of working capital in Laotian family firms. Second, from a financing decisions perspective, we utilize a two-wave design to test our hypotheses regarding the potential cross-lagged correlation between working capital and decision-making. The present study specifically employs a two-wave cross-lagged model for the 2016-2017 period $\left(t_{1}\right)$, then continues for the 2018-2019 period $\left(t_{2}\right)$. Finally, we consider theoretical and empirical evidence for developing competing hypotheses of why working capital affects decision-making, leading to reliable outcomes in certain areas of capital structure decisions.

\section{Literature Review}

\subsection{Family Firms in Laos: Development and Definition}

Three transformations in family firm development in Laos have been noted in previous studies [15]: first, the so-called "public companies", which appeared in 1975; second, "state-owned enterprises" which appeared in 1986; and third, "private family firms" (1986-present). Based on the previous literature, family firms have undergone three historical periods of development, namely the French colonial, Royal Lao Government, and New Economic Mechanism periods. This development largely followed industrial regimes changing from a centrally planned economy to a market-oriented economy, along with the national socio-economic development plan.

Tachibana [16] defined the original Laotian family firms as firms of one or more generation, with an owner-manager and family managers, a private business, fewer than 19 employees, and an annual turnover of about LAK400 million Kip (US\$45,000). According to prior literature, Laotian micro, small, and medium-sized enterprises (MSMEs) are defined using various quantitative criteria in terms of number of employees, business types, and performance [16]. Recent researchers have defined Laotian MSMEs as consisting of 1 to 99 employees [25]. Specifically, according to the Laos Enterprise Survey [26]:

- $\quad$ micro-sized enterprises have $<9$ employees and turnover $\leq$ LAK150 million (US\$17,000)

- $\quad$ small-sized enterprises have $<19$ employees and turnover $\leq$ LAK250 million (US\$30,000)

- medium-sized enterprises have $<199$ employees and turnover $\leq$ LAK400 million (US\$45,000)

This study uses quantitative criteria, considering micro-sized enterprises as having 9 employees, and small-sized enterprises as having 19 employees, with an annual turnover of up to $\leq$ US $\$ 30,000$. Therefore, for the purpose of this study, the definition of family firms adopted by the World Bank [26] is used and applied to $100 \%$ of Laotian family firms. 


\subsection{Decision-Making in Family Firms}

In an earlier study, we utilized the theory of planned behavior to examine various steps of family firms' decision-making [27]. The key ideas of the theory have been linked to entrepreneurial intentions, existing intentions regarding capital structure, and the career decision to enter a family firm [28]. The standard behavioral finance body of research proposes that financial decisions affect the valuation of a succession strategy [29]. However, there is substantial evidence that financial decisions are based on planning behavior, family managerial ability, and reducing the cost of the capital structure [1]. Access to sufficient capital structure is one of the most critical factors that shows the influence of behavioral control in behavioral decisions. The characteristics of decision-making are that it involves an independent and single decision-maker, typically a family-owned firm. Moreover, since family-owned firms are usually the central decision-making entity, they consider multiple finance options and the impact of motivational elements.

The literature here assumes the existence of the theory of planned behavior, and combines it with insight from decision-making [30]. The rationale of decision-making relates to how families might seek to ensure "optimal value," as the driver of efficient firm growth. Thus, the role of the family has been shown to significantly affect the capital structure decisions, specifically regarding the strong preference for financing sources [31]. Indeed, there is an increasing body of literature on financing decisions; for instance, Zhong and Zhang [32] and Kumar and Preeti [33] found that peer effects, rather than correlated effects, play a significant role in determining decision-making. In other words, family firms are highly dependent on a single decision-maker, who determines the firm's financial logic, ownership control, and working capital.

\subsection{Working Capital}

Previous research evidence is based on the analysis of working capital, its determinants, and its relationship with the family firm's profitability [34-36]. Shin and Soenen [37] and Padachi [38] developed a framework for working capital decisions based on the cash conversion cycle, liquidity, current, and debt financing. Currently, Wasiuzzaman's [39] study also investigates the effect on working capital components: that is, accounts receivable and accounts payable. In fact, other studies such as those of Afrifa and Padachi [36], Bhatia and Srivastava [40], and Stephen and Elvis [41] find a relationship between working capital, inventory, growth, and profitability. Thus, Tauringana and Afrifa [42] suggest that working capital should reduce the cost of possible interruptions to production, reduce liability, and maintain higher inventory and cash-conversion cycle time.

Family firms can also adapt working capital by evaluating the trade-off between the expected profitability and risk, before deciding the optimal level of investment. However, Peel and Wilson [43] point out that the modern behavior of finance belief, i.e., deciding to invest in working capital (with aggressive policies) rather than investing heavily in working capital (conservative policies), may also result in higher performance. According to García-Teruel and Martínez-Solano [34], working capital is independent of financial decisions; hence, aggressive and conservative policies have associated costs and benefits. More recently, Le [44] analyzed a large sample in developing countries during the period 2007-2016. His results confirm a negative relationship between net working capital, firm valuation, profitability, and risk. Moreover, he finds that less access to capital is also important when investing in a period economic recovery, as this affects the family firm's performance.

It is observed that the previous literature has scarcely studied the relationship between working capital and decision-making in family firms of Laos. Many researchers highlight the importance of investigating the issue of working capital not only in the context of a certain country, but also in a specific family firm. Hence, no consensus from empirical studies can be reached regarding the cross-lagged effects of working capital and decision-making. Consequently, our study aims to fill this gap and contribute to the literature on working capital and decision-making in socialist transition economies such as Laos. Next, we develop the research hypotheses in greater detail. 


\subsection{Hypothesis Formulation}

The theoretical framework used in the present study is shown in Figure 1. Our study tests a two-wave cross-lagged model that hypothesizes the correlation between working capital and decision-making. Our study examines six dimensions of working capital: access to finance, cash, debt financing, inventory, growth, and profitability [34-43]. First, we test a positive correlation between working capital and decision-making at $t_{1}$ and $t_{2}$ for the main hypothesis, and sub-hypothesize a cross-lagged correlation.

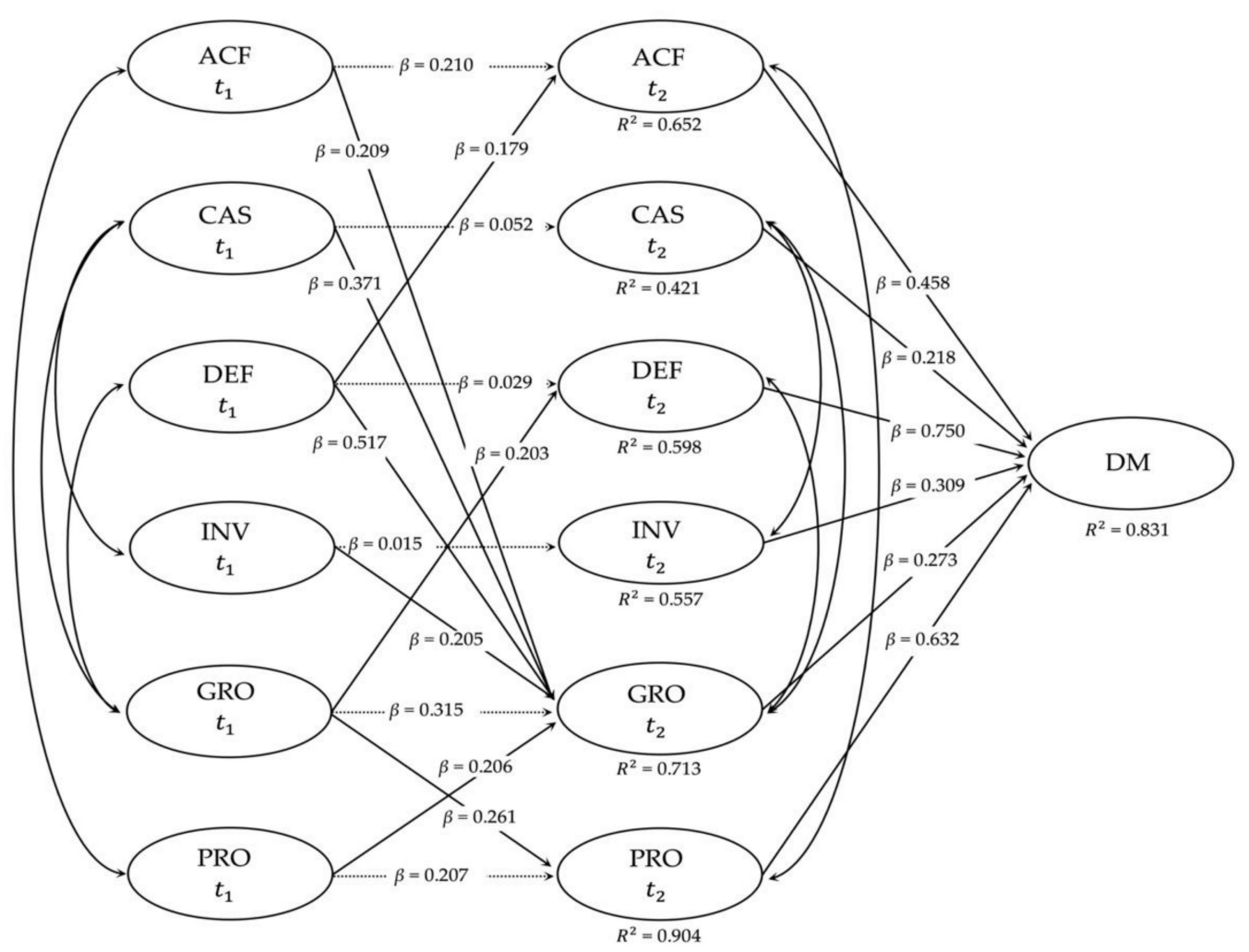

Figure 1. Final cross-lagged model results. Note: $\beta$ : coefficient; $R^{2}$ : coefficient of determination; ACF: access to finance; CAS: cash; DEF: debt financing; INV: inventory; GRO: growth; PRO: profitability; MD: decision-making.

\subsubsection{Access to Finance}

In this study, we follow the basic assumption of access to finance [44], to underpin our hypotheses. We hypothesize that access to finance produces the (cross-lagged) results of resource gains for family firms, and hence leads to decision-making (effect). Similarly, Murro and Peruzzi [21] considered that access to finance has a positive effect, with values driven by credit rationing and lending relationships, but they did not use a cross-lagged approach. Based on the above discussion, one main and one sub-hypothesis are developed for testing:

Hypothesis 1. Access to finance is positively associated with decision-making.

Hypothesis 1a. Access to finance at $\left(t_{1}\right)$ has a positive cross-lagged effect on growth at $\left(t_{2}\right)$.

\subsubsection{Cash}

Considerable working-capital research has demonstrated a positive correlation between cash and decision-making [22]. In numerous studies, cash was found likely to increase the liquidity of family firms [45-47]. They aimed to understand why the planning, managing, and controlling of 
cash in the capital structure affected decision-making. They studied the increase of cash, typically the cash-conversion cycle, in order to investigate its relationship with accounts receivable and payable [48]. However, as current studies are all based on a relationship between variables, as noted earlier, they have not yet hypothesized a cross-lagged correlation. Based on the discussion above, the second hypothesis and one sub-hypothesis are developed for testing:

Hypothesis 2. Cash is positively associated with decision-making.

Hypothesis 2a. Cash at $\left(t_{1}\right)$ has a positive cross-lagged effect on growth at $\left(t_{2}\right)$.

\subsubsection{Debt Financing}

According to the present literature review, researchers [3,39,49] identified two categories of debt financing: internal and external financial sources. According to Chua et al. [50], and Hillier et al. [51], new ventures of family firms are often debt financing through loaning, asset-liability, and debt-credit. Interestingly, they found that family firms have a higher debt-financing preference for risky asset-liability (e.g., times over net worth, total debt, and interest). Given the competing theoretical arguments, lower or higher-debt financial agency costs will affect performance in the future marketplace [52]. Based on the discussion above, the debt-financing effect has not yet been hypothesized in a cross-lagged model. Hence, the following third hypothesis and two sub-hypotheses are developed for testing:

Hypothesis 3. Debt financing is positively associated with decision-making.

Hypothesis 3a. Debt financing at $\left(t_{1}\right)$ has a positive cross-lagged effect on access to finance at $\left(t_{2}\right)$.

Hypothesis $3 \mathbf{b}$. Debt financing at $\left(t_{1}\right)$ has a positive cross-lagged effect on growth at $\left(t_{2}\right)$.

\subsubsection{Inventory}

A significant portion of earlier research on inventory has been extensively devoted to empirical research on working capital [53]. A large inventory may increase a firm's sales and, consequently, its optimization of stock turnover [23]. At present, a number of studies have reported the impact of inventory on working capital and operational decision-making [54-56]. This study identified inventory as consisting of sales growth, return assets levels, average payment period, and cost of goods sold. This means that a longer inventory (raw materials, work-in-process, and finished goods) does not readily affect the working capital of family firms. Based on this, the fourth hypothesis and one sub-hypothesis are developed for testing:

Hypothesis 4. Inventory is positively associated with decision-making.

Hypothesis 4a. Inventory at $\left(t_{1}\right)$ has a positive cross-lagged effect on growth at $\left(t_{2}\right)$.

\subsubsection{Growth}

Growth in the family firms refers to liquidity growth, high-growth opportunities, and choices of investment [57,58]. In the arena of family business research, Saridakis et al. [59] indicated that growth is significantly associated with revenue and firm performance. This study also suggests that high growth may bring more working capital gains to liquidity, return on assets, and profitability. We argue that growth is primarily viewed as its cross-lagged effect on decision-making. Therefore, the fifth hypothesis and two sub-hypotheses are developed for testing:

Hypothesis 5. Growth is positively associated with decision-making.

Hypothesis 5a. Growth at $\left(t_{1}\right)$ has a positive cross-lagged effect on debt financing at $\left(t_{2}\right)$. 
Hypothesis $5 \mathbf{b}$. Growth at $\left(t_{1}\right)$ has a positive cross-lagged effect on profitability at $\left(t_{2}\right)$.

\subsubsection{Profitability}

In family firms, targeting high profitability is a significant area of business growth; efficient working capital leads to improved firm performance and competitive advantage [2,8,24,39-41]. In this study, therefore, we follow the approach used in the previous studies of Afrifa and Padachi [36], Peel and Wilson [43], Moussa [47], and Prasad et al. [53], which proposes that high profitability will be sustained; this will help firms avoid the risk of interruption in loaning and debt financing. Some findings from the aforementioned studies have been consistent, in that family firms achieved a higher profitability, with optimal levels of inventory, accounts receivable, accounts payable, and the cash-conversion cycle. A previous study by Shrivastava et al. [60] also defined profitability as a considerable amount of return on equity, receivable after tax payment, and total assets ratio. A few studies have based their hypotheses on a two-wave design at $t_{1}$, and continued at $t_{2}$, when studying Laotian family firms. Hence, the sixth hypothesis and one sub-hypothesis are developed for testing:

Hypothesis 6. Profitability is positively associated with decision-making.

Hypothesis 6a. Profitability at $\left(t_{1}\right)$ has a positive cross-lagged effect on growth at $\left(t_{2}\right)$.

\section{Methods}

\subsection{Sample and Procedure}

Data were collected from Laotian family firms for 2016 to 2017 at $\left(t_{1}\right)$, and in 2018-2019 at $\left(t_{2}\right)$; the firms were listed in the enterprise survey of Laos [26]. A preliminary survey shows a total of 126,913 firms, comprising 126,717 (99.8\%) small firms and $196(0.2 \%)$ large firms. The majority of family firms are geographically located in Vientiane (32.7\%), Savannakhet $(21.4 \%)$, and other regions $(45.9 \%)$. The sectors are classified as the wholesale and retail trade $(38.5 \%)$, manufacturing $(15.4 \%)$, accommodation and food services (13.9\%), construction (10.7\%), transportation and storage $(8.5 \%)$, and others (13\%).

We adopted a systematic sampling approach: only the firms which supplied data for the entire time period (2016-2019) were considered, and firms with lost values/no values were eliminated, to ensure the data set was consistent. Two criteria were then used to justify the inclusion of a family firm in the sample. First, family firms had to meet the definition of the Prime Minister's Decree No. 42, issued in 2004, with regard to family firm law; this left 78,459 (61.91\%) firms as representative of the whole population. Second, family firms were included in the sample if their data were available for all three years under investigation, from 2016 to 2019. This gave a total of 30,512 (24.07\%) family firms and $10,394(8.20 \%)$ non-family firms. Finally, after deletion of missing data, the sample size consisted of 779 Laotian family firms, which were used to test our hypothesis with a two-wave cross-lagged analysis.

The structured interviews included a validity scale adopted from the relevant literature, and a mean expert rating was conducted to test its accuracy. To ensure the validity of the structured interviews, we selected three professional experts on working capital in family firms, to check that the index of items was objectively congruent in a pilot test. At $t_{1}$, the structured interviews, including questions on demography, working capital components (access to finance, cash, debt financing, inventory, growth, profitability) and decision-making, were conducted with the family firms during the period from 1 December, 2016 to 1 December, 2017. At $t_{2}$ the structured interviews again took place, including the same participants and variables, except demographic variables, held between 1 December, 2018 and 1 December, 2019 (i.e., 1 year after $t_{1}$ ). 


\subsection{Measures}

\subsubsection{Latent Variable}

\section{Decision-Making}

We used decision-making as the latent variable in our study. We measured decision-making by utilizing a scale developed and validated by Koropp et al. [1], and Romano et al. [61]. Our structured interview gauged three dimensions: external debt, internal fund, and external equity. Respondents were also asked to respond to the questions: "How does external finance (bank debt) affect your decision-making?", "Does your internal fund affect your decision-making?", and "Do you intend to use external equity for the family firm investment and decision-making?" All participants were asked to rate a seven-point Likert scale from 1 (do not agree) to 7 (completely agree). The Cronbach's $\alpha$ coefficient for decision-making was 0.841 at $t_{1}$ and 0.865 at $t_{2}$.

\subsubsection{Observed Variables}

\section{Access to Finance}

Measuring access to finance consisted of credit rationing and lending relationships [44], which were developed and validated. Examples of questions include "Are external finance sources significant for your family firm?" and "What is your rationale for lending external finance?" Access to finance was measured with 15 items, with a seven-point Likert scale, ranging from 1 (do not agree) to 7 (completely agree). The Cronbach's $\alpha$ of access to finance was 0.870 at $t_{2}$ and 0.887 at $t_{2}$.

\section{Cash}

Cash was developed and validated by Martínez-Sola et al. [48]. At each wave of data collection, the accounts receivable and accounts payable balance were addressed by the questions: "How do you manage your accounts receivable for the cash-conversion cycle?" and "How do you manage your accounts payable for the cash-conversion cycle?" Cash was measured by 15 items, using a seven-point Likert scale from 1 (do not agree) to 7 (completely agree), with Cronbach's $\alpha$ for the scale being 0.771 at $t_{1}$ and 0.820 at $t_{2}$.

\section{Debt Financing}

Debt financing items were based on those developed by Chua et al. [50], and Hillier et al. [51]. At each wave of data collection, loaning, asset-liability, and debt-credit was also examined by the questions: "Do you use a wide range of external loaning in your family firm?", "Have you considered the use of internal asset-liability?", and "How well does your lending interest rate perform?" The Cronbach's $\alpha$ for the 15-items, assessed from 1 (do not agree) to 7 (completely agree), was 0.890 at $t_{1}$ and 0.905 at $t_{2}$.

\section{Inventory}

Current research seems to validate the measure that inventory is consistent with sales growth, return assets level, average payment period, and cost of goods sold [23,54]. Respondents were also asked to respond to the questions: "Do your sales grow each year?", "How long have you had return assets levels?", "How do you maintain your inventory?", and "How well does the inventory perform on cost of goods sold each year?" Inventory was measured by 15 items, with a seven-point Likert scale from 1 (do not agree) to 7 (completely agree). The Cronbach's $\alpha$ in the current sample was between 0.814 at $t_{1}$ and 0.910 at $t_{2}$. 
Growth

Growth was taken from current research $[57,58]$, with our measures based on liquidity growth, high-growth opportunities, and investment choices. Questions include: "Does liquidity grow each year?", "Does your family firm have a high-growth opportunity?", and "Do investment choices affect your decision-making?" Growth was measured by 15 items, with a seven-point Likert scale, ranging from 1 (do not agree) to 7 (completely agree). The index has a Cronbach's $\alpha$ of 0.820 at $t_{1}$ and 0.925 at $t_{2}$.

\section{Profitability}

Profitability measures were developed and validated by Shrivastava et al. [60], consisting of gross operating income, which was measured as sales growth and revenue. Participants were asked to answer this question: "When a firm has mainly financial assets on its balance sheet, will its operating activities contribute to return on assets?" Profitability was measured by 15 items, with a seven-point Likert scale from 1 (do not agree) to 7 (completely agree). The reliability of this scale was high, with a Cronbach's alpha of 0.889 at $t_{1}$ and 0.910 at $t_{2}$.

\subsection{Cross-Lagged Model}

To identify the effects between working capital and decision-making, a two-wave cross-lagged model was used in this study. The cross-lagged model conducts a two-wave measurement at different time points, representing a score at time $(t)$ as the score variation at time at $(t-1)$ [62]. Thus, this model is particularly appropriate for analysis of occasion-to-occasion transmission data where the score at $\left(t_{2}\right)$ depends on the score at $\left(t_{1}\right)$. The parameter values of the measure at each time point against the same measure at the previous time point are called the "autoregressive coefficient". Then, we construct the score at $\left(t_{1}\right)$ and $\left(t_{2}\right)$ based on the bivariate autoregressive cross-lagged model [63]. We start with an analogous equation of a cross-lagged model:

$$
\begin{aligned}
& y_{i}(t)=\beta_{1} y_{i}(t-1)+\beta_{2} z_{i}(t-1)+e_{i}(t) \\
& z_{i}(t)=\gamma_{1} z_{i}(t-1)+\gamma_{2} \gamma_{i}(t-1)+r_{i}(t)
\end{aligned}
$$

where $\gamma_{i}(t)$ represents the outcome of variables on $\gamma$ for individual $i$ at $(t)$, and $z_{i}(t)$ is presented as $z$ for $i$ at $(t)$. Thus, $y_{i}(t-1)$ and $z_{i}(t-1)$ are measured at $(t-1)$, and $e_{i}(t)$ and $r_{i}(t)$ are the residuals for $i$ at $(t)$. To estimate the coefficients, $\beta_{1}$ and $\gamma_{1}$ are the autoregressive parameters, while coefficients $\beta_{2}$ and $\gamma_{2}$ are the cross-lagged parameters at $(t)$ from the others at $(t-1)$. In our model, autoregressive cross-lagged relations were repeated latent variables rather than the observed scores. The observed scores are summed composites of multiple indicators (items); the assumption of measurement invariance across time can be tested, and retains the same interpretation across the waves.

\subsection{Analyses}

To test our hypotheses, we analyzed the two-wave cross-lagged model results using Stata 15.1 [64]. Before the analysis, we tested whether the observed variables showed any problems regarding the normality assumption of the cross-lagged model. As a model for the test of time-varying paths, each coefficient of the autoregressive paths of latent variables, working capital, and decision-making cross paths was constrained to be equal. For the evaluation of the model's goodness of fit, the chi-squared fit index is highly sensitive to sample size: the value of the root mean square error of approximation (RMSEA) is 0.050, and the values of the comparative fit index (CFI) and Tucker Lewis index (TLI) are $\geq$ $0.950[65,66]$. The coefficient of determination $\left(R^{2}\right)$ ranges from 0 to 1 , and represents the complete model's predictive accuracy; it relies on a "rough" rule of thumb, regarding an acceptable value as between $0.50, p<0.05$ and $0.75, p<0.01$ [67]. 


\section{Results}

\subsection{Descriptive Data and Cross-Lagged Correlations}

Before examining the cross-lagged model, we tested the descriptive data and correlation matrix. The present study involves 487 (62.51\%) family managers and 292 (37.49\%) owner-managers. Among these respondents, $697(89.47 \%)$ were married and $82(10.52 \%)$ were single. Furthermore, 405 (51.98\%) had been educated to high-school level, 211 (27.08\%) had attended vocational school, and 153 (19.64\%) had a bachelor's degree. In all, 351 (45.05\%) had work experience of between one and five years, 257 (32.99) between six and ten years, and 171 (21.95\%) over 11 years. The descriptive statistics and correlation of all variables are presented in Table 1. All variable correlations in a two-wave cross-lagged model, which were the main focus in the present study, indicate that access to finance at $t_{1}$ correlated with $t_{2}(r=0.129, p<0.05)$. The higher cross-lagged correlations of cash at $t_{1}$ correlated with $t_{2}$ $(r=0.510, p<0.01)$. Debt finance at $t_{1}$ correlated with $t_{2}(r=0.337, p<0.01)$. However, the association of inventory $t_{1}$ correlated with $t_{2}(r=0.207, p<0.01)$. In addition, the growth at $t_{1}$ was not correlated significantly at $t_{2}(r=0.056)$. Finally, we found that profitability at $t_{1}$ correlated with $t_{2}(r=0.360$, $p<0.01)$.

Table 1. Descriptive statistics.

\begin{tabular}{|c|c|c|c|c|c|c|c|c|c|c|c|c|}
\hline & 1 & 2 & 3 & 4 & 5 & 6 & 7 & 8 & 9 & 10 & 11 & 12 \\
\hline \multicolumn{13}{|c|}{$t_{1}$} \\
\hline 1. ACF & 1 & & & & & & & & & & & \\
\hline 2. CAS & $0.208 *$ & 1 & & & & & & & & & & \\
\hline 3. DEF & $0.350 *$ & $0.255^{*}$ & 1 & & & & & & & & & \\
\hline 4. INV & $0.411^{* *}$ & $0.492 * *$ & $0.250 *$ & 1 & & & & & & & & \\
\hline 5. GRO & $0.200 *$ & $0.571 * *$ & $0.203 *$ & 0.180 * & 1 & & & & & & & \\
\hline 6. PRO & 0.611 ** & 0.175 * & $0.489^{* *}$ & $0.557^{* *}$ & $0.601 * *$ & $t_{2} 1$ & & & & & & \\
\hline 7. ACF & 0.129 * & 0.327 * & $0.503^{* *}$ & $0.257 *$ & 0.244 * & 0.211 * & 1 & & & & & \\
\hline 8. CAS & 0.700 ** & $0.510^{* *}$ & $0.309^{* *}$ & 0.130 * & 0.097 & $0.380 * *$ & 0.441 & 1 & & & & \\
\hline 9. DEF & $0.450 * *$ & $0.289 *$ & $0.337^{* *}$ & $0.531 * *$ & $0.201 *$ & $0.562 * *$ & $0.346^{* *}$ & $0.303^{* *}$ & 1 & & & \\
\hline 10. INV & $0.133^{* *}$ & 0.260 * & $0.541^{* *}$ & $0.207 *$ & $0.395 * *$ & 0.191 * & 0.160 * & 0.239 * & $0.590^{* *}$ & 1 & & \\
\hline 11. GRO & 0.045 & 0.047 & 0.302 ** & 0.195 * & 0.056 & $0.219 *$ & 0.350 ** & $0.148^{*}$ & 0.422 ** & 0.078 & 1 & \\
\hline 12. PRO & $0.375^{* *}$ & 0.092 & 0.066 & $0.201 *$ & $0.433 * *$ & $0.360 * *$ & 0.301 ** & 0.011 & $0.119^{* *}$ & $0.470 * *$ & 0.230 * & 1 \\
\hline Mean & 0.459 & 0.539 & 0.334 & 0.255 & 0.430 & 0.322 & 0.477 & 0.391 & 0.010 & 0.149 & 0.201 & 0.305 \\
\hline SD & 0.716 & 0.771 & 0.611 & 0.414 & 0.692 & 0.605 & 0.580 & 0.820 & 0.289 & 0.345 & 0.503 & 0.269 \\
\hline$\%$ & 10.501 & 5.870 & 40.650 & 15.844 & 40.319 & 6.881 & 21.467 & 8.190 & 60.053 & 6.920 & 23.651 & 5.409 \\
\hline
\end{tabular}

Note: ${ }^{*} p<0.05,{ }^{* *} p<0.01$; SD: standard error; $\%$ : proportion of total working capital; ACF: access to finance; CAS: cash; DEF: debt financing; INV: inventory; GRO: growth; PRO: profitability.

\subsection{Preliminary Analysis}

The results path model at $t_{1}: \chi^{2}=643.750 ; d f=412 ; p<0.05 ; \mathrm{CFI}=0.951, \mathrm{TLI}=0.958, \mathrm{RMSEA}=$ 0.287. Looking at the cross-lagged effect, guilt at $t_{2}: \chi^{2}=771 ; d f=524 ; p<0.05 ; \mathrm{CFI}=0.962$, TLI $=$ 0.965 , RMSEA $=0.256$. As can be seen in Table 2 , all coefficients of the cross-lagged path model are shown at $t_{1}$ and $t_{2}$. 
Table 2. Comparison of alternative models at $t_{1}$ and $t_{2}$.

\begin{tabular}{|c|c|c|c|c|c|c|c|c|}
\hline & $x^{2}$ & $d f$ & TLI & CFI & RMSEA & $\Delta x^{2}$ & $\Delta d f$ & $p$ \\
\hline & & & & $t_{1}$ & & & & \\
\hline $\mathrm{ACF}$ & 500.519 & 323.668 & 0.963 & 0.971 & 0.008 & - & - & - \\
\hline CAS & 611.110 & 229.164 & 0.961 & 0.951 & 0.006 & 212.339 & 29.411 & 0.153 \\
\hline DEF & 560.519 & 423.668 & 0.961 & 0.959 & 0.005 & 179.416 & 27.556 & 0.158 \\
\hline INV & 504.308 & 323.022 & 0.955 & 0.955 & 0.005 & 128.667 & 28.001 & 0.068 \\
\hline GRO & 578.544 & 273.102 & 0.956 & 0.963 & 0.006 & 205.153 & 28.950 & 0.211 \\
\hline PRO & 604.519 & 244.658 & 0.955 & $\begin{array}{c}0.963 \\
t_{2}\end{array}$ & 0.006 & 210.382 & 30.336 & 0.094 \\
\hline $\mathrm{ACF}$ & 609.001 & 323.121 & 0.965 & 0.984 & 0.005 & - & - & - \\
\hline CAS & 694.519 & 223.998 & 0.959 & 0.971 & 0.004 & 203.937 & 32.445 & 0.194 \\
\hline DEF & 670.210 & 244.519 & 0.951 & 0.961 & 0.003 & 190.172 & 31.151 & 0.251 \\
\hline INV & 609.890 & 223.115 & 0.950 & 0.962 & 0.003 & 203.035 & 30.169 & 0.093 \\
\hline GRO & 624.923 & 209.651 & 0.967 & 0.979 & 0.005 & 215.994 & 34.112 & 0.117 \\
\hline PRO & 710.519 & 323.344 & 0.960 & 0.975 & 0.004 & 229.422 & 33.567 & 0.136 \\
\hline
\end{tabular}

Note: $\chi^{2}$ : chi-squared; $d f$ : degrees of freedom; TLI: Tucker-Lewis index; CFI: comparative fit index; RMSEA: root mean square error of approximation; ACF: access to finance; CAS: cash; DEF: debt financing; INV: inventory; GRO: growth; PRO: profitability.

\subsection{Cross-Lagged Model Results}

Table 3 presents the coefficients among all study variables at $t_{1}$ and $t_{2}$. This results in an acceptable model fit to the data: $\chi^{2}=821.038 ; d f=603 ; p<0.01$; CFI $=0.975$, TLI $=0.981$, RMSEA $=0.001$. The results indicate that working capital affects decision-making from $t_{1}$ to $t_{2}\left(R^{2}=0.831, p<0.01\right)$. To account for this, we found access to finance $\left(R^{2}=0.652, p<0.01\right)$, cash $\left(R^{2}=0.421, p<0.05\right)$, debt financing $\left(R^{2}=0.598, p<0.01\right)$, inventory $\left(R^{2}=0.557, p<0.01\right)$, growth $\left(R^{2}=0.713, p<0.01\right)$, and profitability $\left(R^{2}=0.904, p<0.01\right)$.

Table 3. Cross-lagged model results at $t_{1}$ and $t_{2}$.

\begin{tabular}{ccccc}
\hline & \multicolumn{2}{c}{ Wave $\left(\boldsymbol{t}_{1}\right)$} & \multicolumn{2}{c}{ Wave $\left(\boldsymbol{t}_{2}\right)$} \\
\cline { 2 - 5 } & $\boldsymbol{\beta}$ (SE) & $\mathbf{9 5 \%} \mathbf{C I}$ & $\boldsymbol{\beta}$ (SE) & $\mathbf{9 5 \%}$ CI \\
\hline ACF & $0.210^{*}(0.156)$ & {$[-0.053,0.161]$} & $0.458^{* *}(0.501)$ & {$[-0.032,0.198]$} \\
CAS & $0.052^{*}(0.002)$ & {$[-0.185,0.029]$} & $0.218^{*}(0.188)$ & {$[-0.036,0.185]$} \\
DEF & $0.029^{*}(0.266)$ & {$[-0.094,0.181]$} & $0.750 *(0.266)$ & {$[-0.005,0.201]$} \\
INV & $0.015^{*}(0.011)$ & {$[-0.123,0.091]$} & $0.309 * *(0.118)$ & {$[-0.133,0.080]$} \\
GRO & $0.315^{* *}(0.487)$ & {$[-0.036,0.176]$} & $0.237 *(0.501)$ & {$[-0.008,0.261]$} \\
PRO & $0.207^{* *}(0.504)$ & {$[-0.035,0.178]$} & $0.632 * *(0.411)$ & {$[-0.052,0.160]$} \\
$R^{2}$ & 0.478 & & 0.831 & \\
Adjusted $R^{2}$ & 0.394 & & 0.760 & \\
\hline
\end{tabular}

Note: ${ }^{*} p<0.05, * * p<0.01$; SD: standard errors; $\beta$ : coefficient; $95 \%$ CI: confidence intervals; $R^{2}$ : coefficient of determination; ACF: access to finance; CAS: cash; DEF: debt financing; INV: inventory; GRO: growth; PRO: profitability.

\subsection{Hypothesis Testing}

The results from the two-wave cross-lagged model at $t_{1}$ and $t_{2}$ are displayed in Table 4 . When testing our hypotheses, we found that access to finance has a positive effect on decision-making ( $\beta=0.458, p<0.01)$, thus supporting $\mathrm{H} 1$. To continue, $\mathrm{H} 2$ posits that cash has a positive effect on decision-making $(\beta=0.218, p<0.05)$, which is supported. H3 presumes that debt financing has a positive effect on decision-making $(\beta=0.750, p<0.01)$, and is also supported. The inventory has a positive effect on decision-making $(\beta=0.309, p<0.01)$, thus supporting H4. The results show that growth $(\beta=0.273, p<0.05)$ has a positive effect on decision-making, also supporting H5. Given the relatively strong effects of profitability on decision-making $(\beta=0.632, p<0.01)$, this supports H6. The results for the cross-lagged model at $t_{1}$ and $t_{2}$ are presented in Figure 1. 
Table 4. Summary of hypotheses.

\begin{tabular}{|c|c|c|c|}
\hline & $\beta$ & $p$ - Value & Effect \\
\hline Hypothesis 1 & & & \\
\hline$(\mathrm{H} 1) \mathrm{ACF} \rightarrow \mathrm{MD}$ & 0.458 & $* *$ & + \\
\hline$(\mathrm{H} 1 \mathrm{a}) \mathrm{ACF}\left(\mathrm{t}_{1}\right) \rightarrow \mathrm{GRO}\left(\mathrm{t}_{2}\right)$ & 0.209 & * & + \\
\hline Hypothesis 2 & & & \\
\hline$(\mathrm{H} 2) \mathrm{CAS} \rightarrow \mathrm{MD}$ & 0.218 & * & + \\
\hline $\begin{array}{c}(\mathrm{H} 2 \mathrm{a}) \text { Cash }\left(\mathrm{t}_{1}\right) \rightarrow \mathrm{GRO}\left(\mathrm{t}_{2}\right) \\
\text { Hypothesis } 3\end{array}$ & 0.371 & $* *$ & + \\
\hline$(\mathrm{H} 3) \mathrm{DEF} \rightarrow \mathrm{MD}$ & 0.750 & ** & + \\
\hline$(\mathrm{H} 3 \mathrm{a}) \mathrm{DEF}\left(\mathrm{t}_{1}\right) \rightarrow \mathrm{ACF}\left(\mathrm{t}_{2}\right)$ & 0.179 & $*$ & + \\
\hline $\begin{array}{c}(\mathrm{H} 3 \mathrm{~b}) \mathrm{DEF}\left(\mathrm{t}_{1}\right) \rightarrow \mathrm{GRO}\left(\mathrm{t}_{2}\right) \\
\text { Hypothesis } 4\end{array}$ & 0.517 & ** & + \\
\hline (H4) INV $\rightarrow$ MD & 0.309 & $* *$ & + \\
\hline $\begin{array}{c}(\mathrm{H} 4 \mathrm{a}) \mathrm{INV}\left(\mathrm{t}_{1}\right) \rightarrow \mathrm{GRO}\left(\mathrm{t}_{2}\right) \\
\text { Hypothesis } 5\end{array}$ & 0.205 & * & + \\
\hline$(\mathrm{H} 5) \mathrm{GRO} \rightarrow \mathrm{MD}$ & 0.273 & * & + \\
\hline$(\mathrm{H} 5 \mathrm{a}) \mathrm{GRO}\left(\mathrm{t}_{1}\right) \rightarrow \operatorname{DEF}\left(t_{2}\right)$ & 0.203 & * & + \\
\hline $\begin{array}{c}(\mathrm{H} 5 \mathrm{a}) \text { GRO }\left(\mathrm{t}_{1}\right) \rightarrow \text { PRO } \\
\text { Hypothesis } 6\end{array}$ & 0.261 & * & + \\
\hline$(\mathrm{H} 6) \mathrm{PRO} \rightarrow \mathrm{MD}$ & 0.632 & $* *$ & + \\
\hline$(\mathrm{H} 6 \mathrm{a})$ PRO $\left(\mathrm{t}_{1}\right) \rightarrow \mathrm{GRO}\left(\mathrm{t}_{2}\right)$ & 0.206 & * & + \\
\hline
\end{tabular}

Note: ${ }^{*} p<0.05,{ }^{* *} p<0.01 ; \beta$ : coefficient; + : positive effect: ACF: access to finance; CAS: cash; DEF: debt financing; INV: inventory; GRO: growth; PRO: profitability; MD: decision-making.

\section{Discussion}

Working capital represents a central challenge to family firms in the Laos context. To better understand this issue, we tested the effect of working capital on decision-making from 1 December 2016 to 1 December 2017 at $t_{1}$, and continued to test from 1 December 2018 to 1 December 2019 at $t_{2}$, in a two-wave cross-lagged model. Thus, the present study confirms that in our sample of family firms in Laos, working capital has positive cross-lagged effects on decision-making. There are a number of possible explanations why a cross-lagged effect between access to finance, cash, debt financing, inventory, growth, and profitability would lead to increased levels of decision-making. Overall, these study results are consistent with Le [8], Singhania and Mehta [24], Afrifa and Padachi [36], Moussa [47], and Prasad et al. [53], yet they provide stronger evidence that working capital is a significant driver of strategic decision-making.

This finding supports current studies, such as those of Garcĩa-Teruel and Martĩnez-Solano [2], Molly et al. [19], Singhania and Mehta [24], Michiels and Molly [31], Afrifa and Padachi [36], Tauringana and Afrifa [42], and Moussa [47]. This result means that the most suitable conditions for any family firm to optimize its working capital influence that family firm's decision-making [68]. The results are similar to those found in previous studies that focused on family firms $[17,18,29,30]$; the analyses confirm the important role of working capital in value, as can be seen in the positive sign for decision-making.

We found that access to finance has a positive cross-lagged effect on growth and decision-making, therefore confirming H1, and supporting the initial idea that higher levels of access to capital are positively related to intuitive decisions. However, our study also confirms that the pathway from access to finance to growth is consistent with the results of Murro and Peruzzi [21], Osano and Languitone, [44], and Salehi et al. [45]. These findings are also in line with the assertion of Cowling et al. [69], who found that access to finance, in terms of credit rationing and lending, affect financial decisions. Thus, if family firms have more access to finance sources, this might interfere with their ability to make decisions. This result may have occurred because access to finance is focused on the stock of structure capital decision-making and performance, while firms are intending to grow asset-liability, external debt financing, and credit risk. 
Cash also has a positive effect on decision-making; hence, $\mathrm{H} 2$ is partially supported. Therefore, the results of this study show that there is a significant correlation between cash and decision-making, which is consistent with the findings of Salehi et al. [45]. The extreme version of family firms would be Nagar and Sen's [70] notion of operating the cash-conversion cycle, where liquidity exists in working capital. The results also indicated that the cash is necessary for family firms to engage in a cash-conversion cycle [71]. Along the same lines, Moussa [47] found a significant positive effect when operating cash with decision-making, which will increase generated liquidity and lower the demand for working capital. We have found marginal support for this hypothesis, and on further analysis have found that family firms which are increasing the cash-conversion cycle in Laos engage in this kind of decision-making behavior.

Debt finance showed a significant positive effect on decision-making, which still supports H3. Empirically, prior studies have demonstrated that external debt financing levels are positively affected by decision-making [3]. At first this result appears to be related to most literature, considering the idea that higher debt financing is a rational decision for family firm profitability. Similarly, Cole and Sokolyk's [3] results confirmed that while debt financing is likely to achieve higher levels of revenue three years after firm's start-up, it has no effect on survival and decision-making. These findings indicate that family firms tend to have business debt regarding working capital, leading to similar indebtedness [49]. According to Molly et al. [19], debt financing indirectly affects the total debt rates (short-term and long-term) and debt decisions in family firms.

The results revealed a highly positive correlation effect between inventory and decision-making; therefore, H4 is supported. These results confirmed the findings of previous studies conducted by Benmamoun et al. [23]. Hence, family firms in times of sales growth tend to have a higher return assets level, average payment period, and cost of goods sold. Similarly, previous studies have reported a positive effect on the working capital turnover and inventory turnover [72]. These findings can be interpreted to mean that family firms with higher working capital rely more on inventory to meet their stock of capital needs, which will lead to improved performance. Moreover, Serranoet al. [73] also suggest that the cost of capital in inventory decisions may lead to holding costs for large orders, cost for the shareholder, and financial variability.

Growth has a significant effect on decision-making, meaning that $\mathrm{H} 5$ is supported; that is, growth has a positive cross-lagged effect on debt financing and profitability. These findings indicate that there is an optimal liquidity growth, high-growth opportunities, and investment choices, which maximize decision-making $[59,73]$. This might be due to the growth in Laos; thus, it is important to contextualize our results with the degree of family firm growth $[5,12,14,16]$. Meanwhile, in other countries (e.g., in continental Asia), the growth in family firms is related to working capital and decision-making [11]. These findings mean that high levels of growth will force family firms to make more interest from working capital, resulting in a cash-conversion cycle, future investment choices, and a competitive advantage [74].

The results also illustrated a highly significant positive correlation between profitability and decision-making, which supports H6. These findings confirm those of previous studies conducted by Singhania and Mehta [24], Wasiuzzaman [39], Stephen and Elvis [41], and Prasad et al. [53]. The results show that family firms with higher profitability rates would have increased gross operating income and return on assets, and lower levels of external debt financing. Contrary to the findings of Garcĩa-Teruel and Martĩnez-Solano [3], and Le [8], these results reveal that working capital investment holds optimistic expectations for family firms with higher profitability, such as in return on assets and liquidity. The results suggest that the profitability of investment issues is industry-specific, with different conditions for firms in difference industries [20].

\section{Conclusions}

The study examined the effect of working capital on decision-making in family firms of Laos, using a two-wave cross-lagged model, with six hypotheses and eight sub-hypotheses for testing. 
The results of the current study confirmed that working capital has a positive and cross-lagged effect on decision-making. Prior to the application of the cross-lagged data, we found that the success of working capital in the family firms largely depends on access to finance, cash, debt financing, inventory, growth capital, and profitability with regard to its effects on financial decision-making in family firms. This empirical result supports the findings of Le [8], Daovisan and Chamaratana [14], Michiels and Molly [31], Afrifa and Padachi [36], and Wasiuzzaman [39]. A significant positive correlation was found between working capital and decision-making of the sampled family firms, which is in line with and supports the earlier research [1]. Therefore, optimal working capital is the key factor in moving towards family firms' decision-making; thus, they should reduce external debt, provide optimal internal funds, and support an external equity nexus.

\subsection{Research Implications}

Our study has important managerial implications. It indicates that if family firms hold a highly optimal stock of working capital, this has a major effect on decision-making. This implication is very important for families and owner-managers in enhancing their family firms, in that it is relevant to associate working capital with access to finance, cash, debt financing, inventory, growth, and profitability. This judgment coincides with earlier research [1], where there is a common finding that working capital $[8,39,43]$ is significantly associated with decision-making. Although these practical implications may be contradictory at first glance, the cross-lagged data can be supported by studying the effects of cash holding decisions, evaluating working capital capability, perceiving behavioral control, growing opportunities, and the capital-profitability nexus.

Our study has also tried to bridge the gap between theoretical work on working capital's effect on decision-making $[1,8,17,19,30]$. Most of the existing literature focused on the level of countries $[8,24,31,40]$ or a set of companies $[38,39,41]$. However, our results showed that there are no ideal forms of working capital and decision-making, as the previous literature has stated $[1,17,30]$. Further, our study encourages family firms to be mindful of the optimal stock of working capital gains, family firms' performance, and growth opportunities in their financial choices, rather than relying on risky asset-liability and external debt financing.

\subsection{Limitations and Future Research}

This study was limited to the analysis of panel data for the period of 1 December 2016 to 1 December 2017 at $t_{1}$, and the follow-up from 1 December 2018 to 1 December 2019 at $t_{2}$ (i.e., 1 year after $t_{1}$ ). The study sample comprised 779 Laotian family firms. As a result, conclusions drawn from this study may not be fully generalizable to family firms from different groups in other countries. Therefore, future research should investigate generalizations of the transition family firms. Furthermore, the current design, a cross-lagged study, is not the optimal way of establishing whether working capital of all family firms has reliably led to success in financial decision-making. These practices have been mapped by operational financing decisions $[1,17,30]$, which considerably affect family culture, family cohesion, emotional attachment, financial attitudes, perceived behavioral control, and financial choices.

Author Contributions: H.D. mainly proposed the research design, the preparation of empirical data collection, data analysis, and the first draft of this study. H.L.S. developed the overall idea, reviewed the final draft, and performed the proofreading and editing. All authors have read and agree to the published version of the manuscript.

Funding: This research received no external funding.

Conflicts of Interest: The author(s) declare no potential conflicts of interest with respect to the research, authorship, and/or publication of this article.

\section{References}

1. Koropp, C.; Kellermanns, F.W.; Grichnik, D.; Stanley, L. Financial decision making in family firms: An adaptation of the theory of planned behavior. FAMI Bus. Rev. 2014, 27, 307-327. [CrossRef] 
2. Garcĩa-Teruel, P.J.; Martĩnez-Solano, P. Effects of working capital management on SME profitability. Int. J. Manag. Financ. 2007, 2, 164-177.

3. Cole, R.A.; Sokolyk, T. Debt financing, survival, and growth of start-up firms. J. Corp. Financ. 2018, 50, 609-625. [CrossRef]

4. Boudreaux, C.J.; Nikolaev, B. Capital is not enough: Opportunity entrepreneurship and formal institutions. Small Bus. Econ. 2019, 53, 709-738. [CrossRef]

5. Harvie, C. Micro-, Ssmall- and Medium-Sized Enterprises (MSMEs): Challenges, Opportunities and Sustainability in East Asia. In Trade Logistics in Landlocked and Resource Cursed Asian Countries; Jayanthakumaran, K., Shukla, N., Harvie, C., Erdenetsogt, O., Eds.; Palgrave Macmillan: Singapore, 2019; pp. 155-174.

6. Bhasin, B.; Ng, L.K. Socio cultural impediments to entrepreneurship: Implications for the Lao People's Democratic Republic. J. Entrep. Bus. Econ. 2019, 7, 64-91.

7. Fang, H.C.; Siau, K.L.; Memili, E.; Dou, J. Cognitive antecedents of family business bias in investment decisions: A commentary on "risky decisions and the family firm bias: An experimental study based on prospect theory. Entrep. Theory Pract. 2019, 43, 409-416. [CrossRef]

8. Le, B. Working capital management and firm's valuation, profitability and risk: Evidence from a developing market. Int. J. Manag. Financ. 2019, 15, 191-204. [CrossRef]

9. Faulconbridge, J.R. Business services and the financing of global production networks: The case of global law firms in Southeast Asia. J. Econ. Geogr. 2019, 19, 897-919. [CrossRef]

10. Dinh, T.Q.; Calabrò, A. Asian family firms through corporate governance and institutions: A Systematic Review of the Literature and Agenda for Future Research. Int. J. Manag. Rev. 2019, 21, 50-75. [CrossRef]

11. Eddleston, K.A.; Jaskiewicz, P.; Wright, M. Family firms and internationalization in the Asia-Pacific: The need for multi-level perspectives. Asia Pac. J. Manag. 2019. [CrossRef]

12. Onphanhdala, P.; Suruga, T. Entrepreneurial human capital and micro and small business in Lao PDR. Dev. Econ. 2010, 48, 181-202. [CrossRef]

13. Sayvaya, I.; Kyophilavong, P. Does microfinance reduce poverty in Lao PDR? Int. J. Dev. Issues 2015, 14, 215-230. [CrossRef]

14. Daovisan, H.; Chamaratana, T. Financing accumulation for start-up capital: Insights from a qualitative case study of women entrepreneurs in Lao PDR. J. FAMI Bus. Manag. 2019. [CrossRef]

15. Fry, S. Three transformations of industrial relations in Laos. J. Ind. Relat. 2008, 50, 779-795. [CrossRef]

16. Tachibana, T. How one becomes an 'entrepreneur' in a transition economy: The case of manufacturers in Laos. Dev. Stud. Res. 2014, 1, 186-201. [CrossRef]

17. Newbert, S.; Craig, J.B. Moving beyond socioemotional wealth: Toward a normative theory of decision making in family business. FAMI Bus. Rev. 2017, 30, 339-346. [CrossRef]

18. Ramiah, V.; Zhao, Y.; Moosa, I.; Graham, M. A behavioural finance approach to working capital management. Eur. J. Financ. 2016, 22, 662-687. [CrossRef]

19. Molly, V.; Uhlaner, L.M.; Massis, A.D.; Laveren, E. Family-centered goals, family board representation, and debt financing. Small Bus. Econ. 2019, 53, 269-286. [CrossRef]

20. Yazdanfar, D.; Öhman, P. Debt financing and firm performance: An empirical study based on Swedish data. J. Risk Financ. 2015, 16, 102-118. [CrossRef]

21. Murro, P.; Peruzzi, V. Family firms and access to credit. Is family ownership beneficial? J. Bank. Financ. 2019, 101, 173-187. [CrossRef]

22. Bian, Y.; Lemoine, D.; Yeung, T.G.; Bostel, N.; Hovelaque, V.; Viviani, L.L.; Gayraud, F. A dynamic lot-sizing-based profit maximization discounted cash flow model considering working capital requirement financing cost with infinite production capacity. Int. J. Prod. Econ. 2018, 196, 319-332. [CrossRef]

23. Benmamoun, Z.; Hachimi, H.; Amine, A. Comparison of inventory models for optimal working capital: Case of aeronautics company. Int. J. Eng. 2018, 31, 605-611.

24. Singhania, M.; Mehta, P. Working capital management and firms' profitability: Evidence from emerging Asian countries. South Asian J. Bus. Stud. 2017, 6, 80-97. [CrossRef]

25. Inmyxai, S.; Takahashi, Y. Determining the applicability of feminist theories by examining the mediation and moderation effects on non-economic performance in Lao micro, small, and medium-sized enterprises. Gend. Manag. Int. J. 2011, 26, 457-482. [CrossRef] 
26. World Bank. Enterprise Surveys: Lao PDR Country Profile 2018; World Bank Group: Washington, DC, USA, 2018; pp. 1-12.

27. Armitage, C.J.; Conner, M. Efficacy of the theory of planned behaviour: A meta-analytic review. Br. J. Soc. Psychol. 2001, 40, 471-499. [CrossRef]

28. Hay, M.; Kamshad, K. Small firm growth: Intentions, implementation and impediments. Bus. Strategy Rev. 1994, 5, 49-68. [CrossRef]

29. Bjuggren, P.O.; Sund, L.G. Strategic decision making in intergenerational successions of small- and medium-size family-owned businesses. FAMI Bus. Rev. 2001, 14, 11-23. [CrossRef]

30. Pimentel, D.; Scholten, M.; Couto, J. Fast or slow? Decision-making styles in small family and nonfamily firms. J. FAMI Bus. Manag. 2018, 8, 113-125. [CrossRef]

31. Michiels, A.; Molly, V. Financing decisions in family businesses: A review and suggestions for developing the field. FAMI Bus. Rev. 2017, 30, 369-399. [CrossRef]

32. Zhong, T.; Zhang, T. "Peer effects" in capital structure decision of Chinese firms-empirical investigation based on Chinese a-share listed firms. Nankai Bus. Rev. Int. 2018, 9, 289-315. [CrossRef]

33. Kumar, S.A.; Preeti, B. Macroeconomic antecedents of capital structure decision-making. LBS J. Manag. Res. 2017, 15, 62-80.

34. Pais, M.; Gama, P. Working capital management and SMEs profitability: Portuguese evidence. Int. J. Manag. Financ. 2015, 11, 341-358. [CrossRef]

35. Baños-Caballero, S.; García-Teruel, P.J.; Martínez-Solano, P. Financing of working capital requirement, financial flexibility and SME performance. J. Bus. Econ. Manag. 2016, 17, 1189-1204. [CrossRef]

36. Afrifa, G.; Padachi, K. Working capital level influence on SME profitability. J. Small Bus. Enterp. Dev. 2016, 23, 44-63. [CrossRef]

37. Shin, H.H.; Soenen, L. Efficiency of working capital and corporate profitability. Financ. Pract. Educ. 1998, 8, 37-45.

38. Padachi, K. Trends in working capital management and its impact on firms' performance: An analysis of Mauritian small manufacturing firms. Int. Rev. Bus. Res. Pap. 2006, 2, 45-58.

39. Wasiuzzaman, S. Working capital and profitability in manufacturing firms in Malaysia: An empirical study. Glob. Bus. Rev. 2015, 16, 545-556. [CrossRef]

40. Bhatia, S.; Srivastava, A. Working capital management and firm performance in emerging economies: Evidence from India. Manag. Labour Stud. 2016, 41, 71-87. [CrossRef]

41. Stephen, M.; Elvis, K. Influence of working capital management on firms profitability: A case of SMEs in Kenya. Int. Bus. Manag. 2011, 5, 279-286. [CrossRef]

42. Tauringana, V.; Afrifa, G.A. The relative importance of working capital management and its components to SMEs' profitability. J. Small Bus. Enterp. Dev. 2013, 20, 453-469. [CrossRef]

43. Peel, M.; Wilson, N. Working capital and financial management practices in the small firm sector. Int. Small Bus. J. 1996, 14, 52-68. [CrossRef]

44. Osano, H.M.; Languitone, H. Factors influencing access to finance by SMEs in Mozambique: Case of SMEs in Maputo central business district. J. Innov. Entrep. 2016, 5, 1-16. [CrossRef]

45. Salehi, M.; Mahdavi, N.; Dari, S.Z.A.; Tarighi, H. Association between the availability of financial resources and working capital management with stock surplus returns in Iran. Int. J. Emerg. Mark. 2019, 14, 343-361. [CrossRef]

46. Akono, H.; Nwaeze, E.T. Why and how firms use operating cash flow in compensation. Account. Bus. Res. 2018, 48, 400-426. [CrossRef]

47. Moussa, A. Determinants of working capital behavior: Evidence from Egypt. Int. J. Manag. Financ. 2019, 15, 39-61. [CrossRef]

48. Martínez-Sola, C.; García-Teruel, P.J.; Martínez-Solano, P. Cash holdings in SMEs: Speed of adjustment, growth and financing. Small Bus. Econ. 2018, 51, 823-842. [CrossRef]

49. Diéguez-Soto, J.; López-Delgado, P. Does family and lone founder involvement lead to similar indebtedness? J. Small Bus. Manag. 2019, 57, 1531-1558. [CrossRef]

50. Chua, J.H.; Chrisman, J.J.; Kellermanns, F.; Wu, Z. Family involvement and new venture debt financing. J. Bus. Vent. 2011, 26, 472-488. [CrossRef]

51. Hillier, D.; Martínez, B.; Patel, P.C.; Pindado, J.; Requejo, I. Pound of flesh? Debt contract strictness and family firms. Entrep. Theory Pract. 2018, 42, 259-282. [CrossRef] 
52. Vieira, E. Debt policy and firm performance of family firms: The impact of economic adversity. Int. J. Manag. Financ. 2017, 13, 267-286. [CrossRef]

53. Prasad, P.; Sivasankaran, N.; Paul, S.; Kannadhasan, M. Measuring impact of working capital efficiency on financial performance of a firm. J. Indian Bus. Res. 2019, 11, 75-94. [CrossRef]

54. Bendavid, I.; Herer, Y.T.; Yücesan, E. Inventory management under working capital constraints. J. Simul. 2017, 11, 62-74. [CrossRef]

55. Luo, W.; Shang, K.H. Technical note-Managing inventory for firms with trade credit and deficit penalty. Operat. Res. 2019, 67, 468-478. [CrossRef]

56. Karadağ, H. Cash, receivables and inventory management practices in small enterprises: Their associations with financial performance and competitiveness. Small Enterp. Res. 2018, 25, 69-89. [CrossRef]

57. Al-Najjar, B.; Taylor, P. The relationship between capital structure and ownership structure: New evidence from Jordanian panel data. Manag. Financ. 2008, 34, 919-933. [CrossRef]

58. Cassar, G.; Holmes, S. Capital structure and financing of SMEs: Australian evidence. Account. Financ. 2003, 43, 123-147. [CrossRef]

59. Saridakis, G.; Lai, Y.; Mohammed, A.M.; Hansen, J.M. Industry characteristics, stages of E-commerce communications, and entrepreneurs and SMEs revenue growth. Technol. Forecast. Soc. Chang. 2018, 128, 56-66. [CrossRef]

60. Shrivastava, A.; Kumar, N.; Kumar, P. Bayesian analysis of working capital management on corporate profitability: Evidence from India. J. Econ. Stud. 2017, 44, 568-584. [CrossRef]

61. Romano, C.A.; Tanewski, G.A.; Smyrnios, K.X. Capital structure decision making: A model for family business. J. Bus. Ventur. 2001, 16, 285-310. [CrossRef]

62. Curran, P.J.; Bollen, K.A. The Best of Both Worlds: Combining Autoregressive and Latent Curve Models. In Decade of Behavior. New Methods for the Analysis of Change; Collins, L.M., Sayer, A.G., Eds.; American Psychological Association: Worcester, MA, USA, 2001; pp. 107-135.

63. Hong, S.; You, S.; Kim, E.J.; Kim, J. Multivariate autoregressive cross-lagged modeling of the reciprocal longitudinal relationship between perceived control and academic achievement. Psychol. Rep. 2008, 102, 873-883. [CrossRef] [PubMed]

64. StataCorp. Stata: Release 15, Statistical Software; StataCorp LLC: College Station, TX, USA, 2017.

65. Jöreskog, K.G. A general approach to confirmatory maximum likelihood factor analysis. Psychometrika 1969, 34, 183-202. [CrossRef]

66. Bentler, P.M. Comparative fit indexes in structural models. Psychol. Bull. 1990, 170, 238-246. [CrossRef] [PubMed]

67. Hair, J.F.; Ringle, C.M.; Sarstedt, M. PLS-SEM: Indeed a silver bullet. J. Market. Theory Pract. 2011, 19, $139-151$. [CrossRef]

68. Lampel, J.; Bhalla, A.; Ramachandran, K. Family values and inter-institutional governance of strategic decision making in Indian family firms. Asia Pac. J. Manag. 2017, 34, 901-930. [CrossRef]

69. Cowling, M.; Liu, W.; Zhang, N. Did firm age, experience, and access to finance count? SME performance after the global financial crisis. J. Evol. Econ. 2018, 28,77-100. [CrossRef]

70. Nagar, N.; Sen, K. How does regulation affect the relation between family control and reported cash flows? Comparative evidence from India and the United States. Corp. Gov. Int. Rev. 2016, 24, 490-508. [CrossRef]

71. Shahzad, F.; Rehman, I.; Colombage, S.; Nawaz, F. Financial reporting quality, family ownership, and investment efficiency. Manag. Financ. 2019, 45, 513-535. [CrossRef]

72. Wibowo, S.S.A.; Rohyati, E. The effect of working capital turnover and profitability of inventory turnover manufacturing companies listed in Indonesia stock exchange. J. Appl. Account. Taxat. 2018, 3, 95-98.

73. Megaravalli, A.; Sampagnaro, G. Predicting the growth of high-growth SMEs: Evidence from family business firms. J. FAMI Bus. Manag. 2019, 9, 98-109. [CrossRef]

74. Belitski, M.; Desai, S. Female ownership, firm age and firm growth: A study of South Asian firms. Asia Pac. J. Manag. 2019. [CrossRef]

(C) 2020 by the authors. Licensee MDPI, Basel, Switzerland. This article is an open access article distributed under the terms and conditions of the Creative Commons Attribution (CC BY) license (http://creativecommons.org/licenses/by/4.0/). 